\title{
Oral Application of Charcoal and Humic Acids Influence Selected Gastrointestinal Microbiota, Enzymes, Electrolytes, and Substrates in the Blood of Dairy Cows Challenged with Glyphosate in GMO Feeds
}

Henning Gerlach ${ }^{1}$, Achim Gerlach ${ }^{2}$, Wieland Schrödl ${ }^{1}$, Svent Haufe ${ }^{4}$, Bernd Schottdorf ${ }^{3}$, Awad A. Shehata ${ }^{1,5}$ and Monika Krüger ${ }^{1 *}$

${ }^{1}$ Institute of Bacteriology and Mycology, Veterinary Faculty, University of Leipzig, An den Tierkliniken 29, D-04103 Leipzig, Germany

${ }^{2}$ Waldstraße 78, D-25712 Burg, Germany

${ }^{3}$ Carbon Terra GmbH Gutermannstrasse 25, D-86154 Augsburg, Germany

${ }^{4}$ WH Pharmawerk Weinböhla GmbH, Poststr. 58, D-01689 Weinbohla, Germany

${ }^{5}$ Avian and Rabbit Diseases Department, Faculty of Veterinary Medicine, Sadat City University, Egypt

\begin{abstract}
The present study was initiated to investigate the influence of oral application of charcoal, sauerkraut juice and humic acids on specific gastrointestinal microbiota and selected enzymes, electrolytes, and substrates in the blood of dairy cows fed GMO feeds containing glyphosate. A total of 380 Schleswig Holstein cows suffering from symptoms of chronic botulism were fed sequentially with $400 \mathrm{~g} /$ animal charcoal daily for 4 weeks (weeks 1-4 of the study), $200 \mathrm{~g} /$ animal charcoal (weeks 5-10 of the study), $200 \mathrm{~g}$ charcoal and $500 \mathrm{ml}$ Sauerkraut juice/animal (weeks 11-14 of the study), $120 \mathrm{~g} /$ animal humic acids (weeks $15-18$ of the study) $200 \mathrm{~g}$ charcoal and $100 \mathrm{~mL}$ Aquahumin/animal (weeks 1920 the of study), or $100 \mathrm{~g}$ charcoal and $50 \mathrm{~mL}$ Aquahumin (weeks 21-22 of the study) followed by 4 weeks without any supplementation. There was a significant reduction of glyphosate in urine following supplementation with a combination of $200 \mathrm{~g}$ charcoal plus either $500 \mathrm{~mL}$ sauerkraut juice or humic acid. From all of the parameters investigated in blood and urine, distinctive effects were only seen as a lack of manganese and cobalt and a significant reduction of creatinine excretion by urine. All other measured parameters such as creatine kinase (CK), alkaline phosphatase (AP), glutamate dehydrogenase (GLDH), glutamate oxaloacetate transaminase (GOT), and cholesterol, urea, and blood creatinine) were not significantly changed. A significant increase of fecal Gram-negative bacteria and enterococci were only seen at week 8 (200 g charcoal/d) and week 20 (200 g charcoal+100 mL Aquahumin). In conclusion, a charcoal-sauerkraut juice combination and humic acids reduced glyphosate excretion by urine and led to the improved health of animals.
\end{abstract}

Keywords: Glyphosate; Charcoal; Sauerkraut juice; Humic acids; Fecal bacteria; Enzymes; Electrolytes; Substrates in blood

\section{Introduction}

Health and performance of high yielding dairy cows depend on a lot of interacting factors of the environment, feed and management [1]. Investigated 240 Danish dairy cows on eight farms (15 fresh calving, 15 high yielding cows at each farm) to evaluate relationships between the regular intake of glyphosate ( $\mathrm{N}$-(phosphonomethyl) glycine) in feed, as measured by excretion in urine, and changes in serum biochemistry, especially enzymes indicative of cytotoxicity such as AP, CK, GLDH, GOT; parameters demonstrating nephrotoxicity (urea, creatinine); a lipid pathway parameter (cholesterol); as well as the trace elements copper $(\mathrm{Cu})$, cobalt $(\mathrm{Co})$, manganese $(\mathrm{Mn})$, selenium $(\mathrm{Se})$, and zinc $(\mathrm{Zn})$. They found increased blood serum parameters indicative of cytotoxicity such as GLDH, GOT, and CK and the lipid profile marker cholesterol in cows at all farms; and high urea levels in half of the farm animals. These results suggest a previously unanticipated impact of glyphosate based herbicides on food animal production.

Glyphosate is a highly effective, broad-spectrum herbicide that inhibits 5-enolpyruvyl shikimate 3-phosphate synthase (EPSPS), an enzyme of the shikimate pathway that is necessary to synthesize aromatic amino acids and other aromatic components in higher plants, algae, bacteria and fungi [2]. The herbicidal action is generated by chelating manganese required in the reduction of the flavin mononucleotide (FMN) co-factor of EPSPS [3]. Glyphosate is the most extensively used herbicide worldwide. The intensive use of glyphosate, especially in GMO forage and grain crops, has led to its wide-spread contamination of different ecosystems where it influences plants, microorganisms, animals and many components of the food chain. Moreover, glyphosate and its primary metabolite aminomethylphosphonate (AMPA) have been also detected in immature seed [4], harvested seeds [5], and ground water [6] accessible to farm animals.

Reducing the activity of glyphosate in the gastrointestinal tract with binders or neutralizers could be a solution to remove this contamination. Mazzei and Piccolo [7] found that glyphosate may spontaneously and significantly bind to soluble humic matter by non-covalent interactions at slightly acidic $\mathrm{pH}$. These results were confirmed by in vitro neutralizing assays with glyphosate sensitive enterococci Shehata et al., with different humic acid products [8]. Gerlach et al. Investigated the influence of oral applications of humic acids (WH67) and charcoal (another absorbent substrate) as well as a combination of charcoal and sauerkraut juice for treatment intervals of four weeks to Holstein Friesian dairy cows on one farm (380 cows) in Germany with clinical signs of chronic botulism [9]. They reported that nearly all supplementations, except low doses of charcoal (200 g / animal and day) alone, led to a significant reduction of C. botulinum $\mathrm{ABE}$ and $\mathrm{CD}$ antibody levels. There was a significant reduction in

*Corresponding author: Monika Krüger, Institute of Bacteriology and Mycology, Veterinary Faculty, University of Leipzig, An den Tierkliniken 29, D-04103 Leipzig, Germany, Tel: 0049-03419738482; E-mail: mkrueger@vetmed.uni-leipzig.de

Received July 21, 2014; Accepted December 20, 2014; Published December 22,2014

Citation: Gerlach H, Gerlach A, Schrödl W, Haufe S, Schottdorf B, (2014) Oral Application of Charcoal and Humic Acids Influence Selected Gastrointestinal Microbiota, Enzymes, Electrolytes, and Substrates in the Blood of Dairy Cows Challenged with Glyphosate in GMO Feeds. J Environ Anal Toxicol 4: 256. doi: 10.4172/2161-0525.1000256

Copyright: @ 2014 Gerlach H, et al. This is an open-access article distributed under the terms of the Creative Commons Attribution License, which permits unrestricted use, distribution, and reproduction in any medium, provided the original author and source are credited. 
Citation: Gerlach H, Gerlach A, Schrödl W, Haufe S, Schottdorf B, (2014) Oral Application of Charcoal and Humic Acids Influence Selected Gastrointestinal Microbiota, Enzymes, Electrolytes, and Substrates in the Blood of Dairy Cows Challenged with Glyphosate in GMO Feeds. J Environ Anal Toxicol 4: 256. doi: 10.4172/2161-0525.1000256

Page 2 of 6

glyphosate excretion by urine after four weeks supplementation with a combination of $200 \mathrm{~g}$ charcoal plus $500 \mathrm{~mL}$ sauerkraut juice/d or $120 \mathrm{~g}$ humic acid/d [10]. The present paper reports the results of a sequential study with different treatments, each lasting four weeks, on a $380 \mathrm{cow}$ dairy farm over 26 weeks. The above mentioned treatment parameters (selected enzymes, electrolytes, and substrates in blood serum or whole blood as well microbiological parameters of feces) were investigated after each change of supplementation (each four week period) or four weeks after finishing all supplementations. To get information about the influence of the treatments on the fecal microbiota, specific microbiological parameters of feces were investigated [11].

\section{Material and Methods}

\section{Animals and supplementations}

A Schleswig Holstein dairy cow farm of about 380 cows with average milk production of $9000 \mathrm{~L}$ per year showed clinical symptoms of chronic botulism (stiff stilted gait, paresis, apathy, engorged veins on tarsus, positive venous pulse, mucous saliva, reduced tail tonus, small wounds in the udder region) in $10-15 \%$ of the cows. $60 \%$ of the cows suffered from Dermatitis digitalis (mortellaro). The entire animal population was involved in the various treatments (400 $\mathrm{g}$ or $200 \mathrm{~g} / \mathrm{d}$ charcoal ( $\leq 8 \mathrm{~mm}$ diameter); a combination of $200 \mathrm{~g}$ charcoal plus $500 \mathrm{~mL} / \mathrm{d}$ sauerkraut juice; $120 \mathrm{~g} / \mathrm{d}$ powdered humic acid (WH67); or a combination of $100 \mathrm{~mL}$ liquid humic acid (Aquahumin) plus $200 \mathrm{~g}$ charcoal/d for two weeks followed with a combination of 50 $\mathrm{mL}$ Aquahumin plus $100 \mathrm{~g}$ charcoal/d for two weeks). After each completed treatment interval, blood specimens, urine and feces from 10 similar cows of the $1^{\text {st }}, 2^{\text {nd }}$, and $3^{\text {rd }}$ lactation and the dry cows group were collected for analytical investigation. The last polyvalent Clostridial vaccination (Covexin, Intervet) was on 01.11.2012. The treatment regime with charcoal, sauerkraut juice, humic acids and their combinations was changed every 4 weeks (supplementation periods) is shown in Table 1. All of the supplements were thoroughly mixed with the feed and given as a total mixed ratio (TMR). The TMR was composed of grass and maize silage (glyphosate concentration was not tested), concentrated mixed feed ( $1.93 \mathrm{mg} / \mathrm{kg}$ glyphosate), ground grains $(0.51 \mathrm{mg} / \mathrm{kg}$ glyphosate), wheat straw $(0.03 \mathrm{mg} / \mathrm{kg}$ glyphosate $)$ and alfalfa hay $(0.02 \mathrm{mg} / \mathrm{kg}$ glyphosate $)$. After $31.03 .2013,10 \mathrm{~kg}$ draff/ cow $(0.01 \mathrm{mg} / \mathrm{kg}$ glyphosate) was fed. At each sampling point, each of the 40 treated cows was evaluated for clinical symptoms of chronic botulism (Table 2).

\section{Collection of samples}

Blood, feces and urine were analyzed 7 times at 4 week intervals with one exception ( $200 \mathrm{~g}$ charcoal after 6 weeks). Two blood specimens were taken from the Vena coccygena mediana. The coagulated blood sample was centrifuged at $3000 \mathrm{x}$ g for $15 \mathrm{~min}$ and the serum samples were stored at $-20^{\circ} \mathrm{C}$ while the whole blood sample was also stored at $-20^{\circ} \mathrm{C}$. Feces were taken from Ampulla recti and spontaneous urinations were sampled and stored at $-20^{\circ} \mathrm{C}$. All specimens were quickly cooled and sent to the laboratory.

\section{Glyphosate testing of urine}

Urine samples were diluted 1:20 with distilled water (aqua distillated, Braun, Germany) and tested for glyphosate by ELISA (Abraxis, USA) according to the manufacturer's instructions. Test validation was done with Gas Chromatography-Mass Spectroscopy (GC-MS) by Medizinsches Labor Bremen (Germany). The correlation coefficient between the two tests was 0.96 (Data not shown).

\section{Analysis of blood serum and whole blood for selected enzymes, electrolytes, and substrates}

Blood serum parameters indicative of cytotoxicity (alkaline phosphatase, AP; glutamate dehydrogenase, GLDH; glutamate oxaloacetate transaminase, GOT; and creatin kinase, and nephrotoxicity (urea and creatine in blood and urine ), and cholesterol were determined. Trace elements $(\mathrm{Mn}, \mathrm{Co}, \mathrm{Se}, \mathrm{Cu}, \mathrm{Zn})$ in whole blood were measured. All analyses were done by the accredited diagnostic laboratory, Labor Schottdorf MVZ GmbH Augsburg.

\section{Microbiological investigations of feces}

The 480 fecal specimens collected from the 40 selected cows every two weeks were investigated by conventional microbiological culture techniques. Fecal specimens ( $0.5 \mathrm{~g}$ in $4.5 \mathrm{~mL}$ PBS) were serially diluted in PBS for quantitative bacterial analysis. Dilutions were tested for total aerobe cell numbers (sheep blood agar, Oxoid, Germany), Gram negative cell numbers (Gassner agar, SIFIN, Berlin), enterococci (CATC agar, SIFIN, Berlin), C. perfringens (sheep blood agar with polymyxin B and neomyacine), and yeasts (Sabouraud agar, SIFIN, Berlin).

\section{Statistical analysis}

The statistical program SPSS 15 (SPSS Inc. Headquarters, $233 \mathrm{~S}$. Wacker Drive, 11th floor, Chicago, Illinois 60606) was used to analyze

\begin{tabular}{|c|c|c|c|c|c|c|c|}
\hline & SP1* & SP2 & SP3 & SP4 & SP5 & SP6 & SP7 \\
\hline Date & $\begin{array}{l}11.11 .2012 \\
-08.12 .2012\end{array}$ & $\begin{array}{l}9.12 .2012 \\
-20.01 .2013\end{array}$ & $\begin{array}{l}21.01 .2013 \\
-17.02 .2013\end{array}$ & $\begin{array}{l}\text { 18.02. } 2013 \\
-17.03 .2013\end{array}$ & $\begin{array}{l}18.03 .2013 \\
-31.03 .2013\end{array}$ & $\begin{array}{l}01.04 .2013 \\
-14.04 .2013\end{array}$ & $\begin{array}{l}15.04 .2013 \\
-14.05 .2013\end{array}$ \\
\hline Supplements & $400 \mathrm{~g} \mathrm{CC}^{1}$ & $200 \mathrm{~g} \mathrm{CC}$ & $\begin{array}{l}200 \mathrm{~g} \mathrm{CC}+ \\
500 \mathrm{~mL} \mathrm{SJ}\end{array}$ & $120 \mathrm{~g} \mathrm{HA}^{3}$ & $200 \mathrm{~g} \mathrm{CC}^{2}+100 \mathrm{~mL} \mathrm{AH}{ }^{4}$ & $100 \mathrm{~g} \mathrm{CC}+50 \mathrm{~mL} \mathrm{AH}$ & $\begin{array}{l}\text { Without } \\
\text { supplements }\end{array}$ \\
\hline
\end{tabular}

*Supplementation period, 1CC=Charcoal (Carbo ligni, Schottdorf, Germany), 2SJ=Sauerkraut juice (Kronprinz Konserven, Meldorf, Germany), 3HA=humic acids WH67 (Pharmawerk Weinböhla, Germany), 4AH=Aquahumin (Pharmawerk Weinböhla, Germany)

Table 1: Overview of the various supplementation times

\begin{tabular}{|l|c|c|c|c|c|c|c|}
\hline & 06.01 .2013 & 20.01 .2013 & 17.02 .2013 & 03.02 .2013 & 03.03 .2013 & 17.03 .2013 & 31.03 .2013 \\
\hline Paresis & $2 / 40$ & $2 / 40$ & $3 / 40$ & $3 / 40$ & $2 / 40$ & $2 / 40$ \\
\hline Cystitis & $2 / 40$ & $2 / 40$ & $2 / 40$ & $1 / 40$ & $4 / 40$ & $1 / 40$ \\
\hline Diarrhea & $5 / 40$ & $0 / 40$ & $3 / 40$ & $7 / 40$ & $0 / 40$ & $3 / 40$ \\
\hline Viscous saliva & $0 / 40$ & $0 / 40$ & $0 / 40$ & $0 / 40$ & $1 / 40$ & $2 / 40$ \\
\hline Endometritis & $0 / 40$ & $1 / 40$ & $0 / 40$ & $0 / 40$ & $0 / 40$ & 0 \\
\hline Ataxia & $0 / 40$ & $0 / 40$ & $0 / 40$ & $0 / 40$ & $0 / 40$ & 0 \\
\hline
\end{tabular}

Table 2: Clinical evaluation of cows at the various sampling points 
Citation: Gerlach H, Gerlach A, Schrödl W, Haufe S, Schottdorf B, (2014) Oral Application of Charcoal and Humic Acids Influence Selected Gastrointestinal Microbiota, Enzymes, Electrolytes, and Substrates in the Blood of Dairy Cows Challenged with Glyphosate in GMO Feeds. J Environ Anal Toxicol 4: 256. doi: 10.4172/2161-0525.1000256

Page 3 of 6

data. The recorded parameters were tested for normal distribution by the Shapiro-Wilkinson Test. Normal distribution of the arithmetic mean and standard deviations were calculated and median and $1^{\text {st }}$ and $3^{\text {rd }}$ quartiles were calculated for abnormally distributed values. Significance tests were performed using Fisher's Exact Test and the Mann-Whitney U Test.

\section{Results}

\section{Glyphosate results}

There was a significant $(\mathrm{P}<0.001)$ reduction of glyphosate output at week 14 (after 4 weeks of $200 \mathrm{~g} / \mathrm{d}$ charcoal plus $500 \mathrm{~mL}$ sauerkraut juice/d) and at week 18 (after 4 weeks of $120 \mathrm{~g} / \mathrm{d}$ humic acids WH67).

\section{Microbiological investigation of faeces}

Yeasts (about $\left.10^{3-4} \mathrm{cfu}\right)$ and $C$. perfringens $\left(10^{3} \mathrm{cfu}\right)$ were not significantly different between any of the 12 investigation time points. The results of total aerobe bacteria, Gram-negative bacteria and enterococci are shown in Figures 1-3. The figures show a similar significant increase of the three bacteriological parameters at weeks $8(\mathrm{P}<0.001)$ and $20(\mathrm{P}<0.001)$. Aerobe bacterial counts also increased significantly $(\mathrm{P}<0.001)$ at week 16 and week $22(\mathrm{P}<0.01)$, and decreased significantly at week $18(\mathrm{P}<0.001)$ and week $26(\mathrm{P}<0.01)$.

\section{Trace elements in whole blood}

Changes in the concentration of trace elements in whole blood are shown in figures 4 A-D. The Se was above the reference value of $70-$ $100 \mu \mathrm{g} / \mathrm{L}$ at all sampling times (mean concentrations of $157,61 \pm 40,52$; $157,48 \pm 19,73 ; 153,68 \pm 14,79 ; 159,00 \pm 16,89 \mu \mathrm{g} / \mathrm{L})$. Co increased significantly $(\mathrm{P}<0.05)$ at week 26 but the concentration was well below the reference value of 21.2-107.2 $\mu \mathrm{g} / \mathrm{l}$ (Figure 4B). Cu was in the normal range (reference $1,020-2,030 \mathrm{mg} / \mathrm{l}$ ) at all sampling times although there was a significant $(\mathrm{P}<0.05)$ increase at week 22 and 26 in relation to the starting point. $\mathrm{Zn}($ Figure $4 \mathrm{D})$ declined significantly $(\mathrm{P}<0.05)$ from the starting point but all the mean levels were above the reference value of $0.7-1.3 \mathrm{mg} / \mathrm{L}$. Mn was significantly reduced after supplementation with different substrates (Figure 4C), and was well below the reference range of $0,36-1,8 \mu \mathrm{mol} / \mathrm{L}$ at all of the sampling times.

\section{Enzymes and substrates in blood serum}

Enzyme and substrate analyses are shown in Table 3. Significant differences between the applied substrates were seen in GOT, urea, urine creatinine and glyphosate in urine. The other investigated parameters were within the reference range.

\section{Discussion}

This sequential study over 26 weeks at this dairy farm with a very high average C. botulinum type CD antibody level (about $600 \%$ of the normal dairy cow level) and a slightly higher average C. botulinum type ABE antibody level (about $150 \%$ of the normal dairy cow level), demonstrate the capacity of these animals to react to the C. botulinum bacterial cell components and neurotoxins with high antibody levels. The presentation of bacterial components and toxins by macrophages depends on the activity of amino peptidases, proteolytic enzymes that hydrolyze peptide bonds from the amino termini of polypeptide chains. Amino peptidases are ubiquitous enzymes that are widely distributed throughout the biological kingdoms and are found in many subcellular organelles, in cytoplasm, and as membrane components where they perform essential cellular functions. They may hydrolyze the first peptide bond in a polypeptide chain with the release of a single amino acid residue (amino peptidases in a strict sense) or they may remove dipeptides or tripeptides (dipeptidyl- and tripeptidylpeptidases) from polypeptide substrates. Most of the amino peptidases are metalloenzymes but cysteine and serine peptidases are also included in this group. The strict metallo-aminopeptidases constitute the largest and the most homogenous class of these enzymes, and use one or two metal ions in their active sites to specifically release the $\mathrm{N}$-terminal amino acid residues of polypeptides and proteins. Amino peptidases act in concert with other peptidases to complete diverse proteolytic pathways. They play a vital role in a range of biological processes and disease situations. Processes as distinct as angiogenesis, antigen presentation, neuropeptide and hormone processing, pregnancy

\begin{tabular}{|c|c|c|c|c|c|c|c|c|}
\hline parameters & Week 0 & week 4 & week 10 & week 14 & week 18 & week 22 & week 26 & Ref. \\
\hline & Range (mean) & Range (mean) & Range (mean) & Range (mean) & Range (mean) & Range (mean) & Range (mean) & \\
\hline $\mathrm{CK}(\mathrm{U} / \mathrm{L})$ & $69-2750(211)$ & $56-450(131)$ & $48-251(120)$ & $66-675(146)$ & $51-675(123)$ & $57-1430(152)$ & $11.3-196(106)$ & $\leq 100$ \\
\hline GLDH (U/L) & $5.5-47(16.8)$ & $3.1-46.6(16.9)$ & $3.3-46.8(16.8)$ & $3-80(19.9)$ & $3.1-186(21.1)$ & $3.5-96(13.9)$ & $3.7-1756(63.2)$ & $\leq 30$ \\
\hline AP (U/L) & $17-68(38.2)$ & $17-77$ (39.3) & $17-76(39.6)$ & $15-87(38.5)$ & $15-87(39.9)$ & $20-70(38)$ & $19-204(44.6)$ & $\leq 300$ \\
\hline GOT (U/L) & $53-155(78.3)$ & $44-116(69.5)^{*}$ & $43-113(70.8)^{* *}$ & $53-173(85.5)^{\star *}$ & $53-178(84)^{* *}$ & $51-148(73)$ & $46-159(81)$ & $\leq 80$ \\
\hline Chol. (mg/dL) & $57-213(138.8)$ & $47-177(116)$ & $63-208(127.4)$ & $30-220(131.1)$ & $10-220(133.7)$ & $3-218(73.9)$ & $77-196(140)$ & $>75$ \\
\hline Urea B (mg/dL) & $14-46(22.6)^{*}$ & $12-30(22.2)^{\star}$ & $6-39(25.7)$ & $5-33(24.4)$ & $5-38(26.5)$ & $5-35(24.7)$ & $7-106(29.5)^{\star *}$ & $20-30$ \\
\hline Crea./Ub (g/L) & $0.2-2.2(1.2)^{*}$ & $0.2-2.9(1.1)$ & $0.2-2.9(0.8)^{\star \star}$ & $0.1-2.4(0.67)^{\star *}$ & $0-2.4(0.6)^{\star * *}$ & $0-1.3(0.7)^{\star * *}$ & $0-1.3(0.3)^{* * *}$ & $2.49-8.02$ \\
\hline Crea./Ba $(\mathrm{mg} / \mathrm{dL})$ & $0.6-1.1(0.8)$ & $0.5-1.3(0.8)$ & $0.7-1.51(0.87)$ & $0.2-1.2(0.79)$ & $0.2-1.28(0.8)$ & $0.6-1.2(0.8)$ & $0.6-3.1(1.0)$ & $1--2$ \\
\hline Vit. B12 (ng/mL) & $98-715(242.8)$ & $114-2190(282)$ & $106-601(225.1)$ & $-c$ & - & - & - & \\
\hline Glyphosate (ng/mL) & $0.5-27.8(15,4)^{*}$ & $1.1-29.4(14,7)$ & $0.5-28.4(11,9)$ & $1.7-22(6.0)^{\star \star}$ & $0.5-22(5.1)^{\star *}$ & $3.4-28.6(18.6)$ & $1.3-36.4(12)$ & 0 \\
\hline
\end{tabular}

150-396

${ }^{a}$ Crea./B-creatinine, blood, ${ }^{b}$ Crea./U-Creatinine, urine, ${ }^{\mathrm{c}}-$ not tested. $(\mathrm{N}=40$ every two weeks)

${ }^{*}=p<0.05,{ }^{* *} P<0.01,{ }^{* * *} P<0.001$

Table 3: Enzyme activity and substrate concentrations in blood serum and creatinine in urine of dairy cows supplemented with charcoal, charcoal with sauerkraut juice or humic acids 
Citation: Gerlach H, Gerlach A, Schrödl W, Haufe S, Schottdorf B, (2014) Oral Application of Charcoal and Humic Acids Influence Selected Gastrointestinal Microbiota, Enzymes, Electrolytes, and Substrates in the Blood of Dairy Cows Challenged with Glyphosate in GMO Feeds. J Environ Anal Toxicol 4: 256. doi: 10.4172/2161-0525.1000256

Page 4 of 6

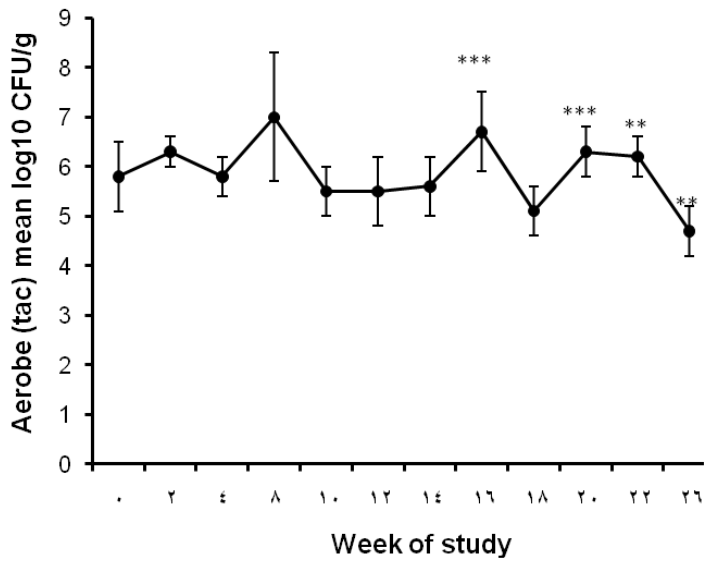

Figure 1: Total aerobe counts in feces of cows supplemented with $400 \mathrm{~g}$ (week 0-4) or $200 \mathrm{~g}$ (week 5-10) charcoal/d, $200 \mathrm{~g}$ charcoal plus $500 \mathrm{~mL}$ sauerkraut juice/d (week 11-14), 120g humic acid/d (week 15-18), 200g charcoal plus $100 \mathrm{ml}$ Aqua humin (week 19-20), $100 \mathrm{~g}$ charcoal plus $50 \mathrm{~mL}$ Aqua humin (week 21-22), and without supplementation (week 23-26). *** $\mathrm{P}<0.001,{ }^{* *} \mathrm{P}<0.01,(\mathrm{~N}=40)$

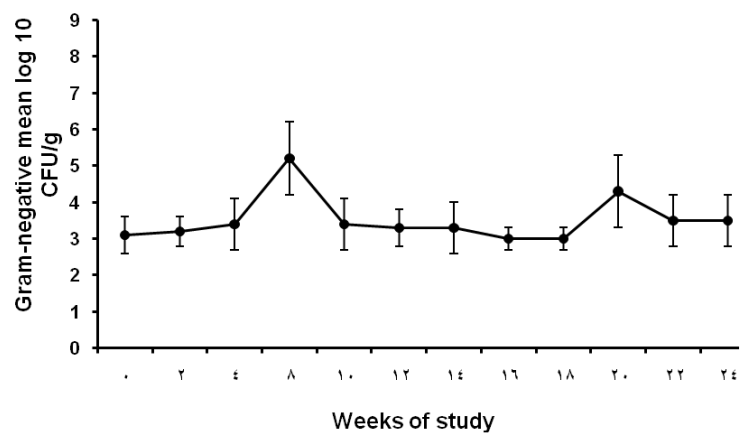

Figure 2: Gram-negative bacteria in feces of cows supplemented with $400 \mathrm{~g}$ (week $0-4$ ) or $200 \mathrm{~g}$ (week 5-10) charcoal $/ \mathrm{d}, 200 \mathrm{~g}$ charcoal plus $500 \mathrm{~mL}$ sauerkraut juice/d (week 11-14), $120 \mathrm{~g}$ humic acid /d (week 15-18), $200 \mathrm{~g}$ charcoal plus $100 \mathrm{ml}$ Aqua humin (week 19-20), 100g charcoal plus $50 \mathrm{~mL}$ Aqua humin (week 21-22), and without supplementation (week 23-26). *** $\mathrm{P}<0.001,(\mathrm{~N}=40)$.

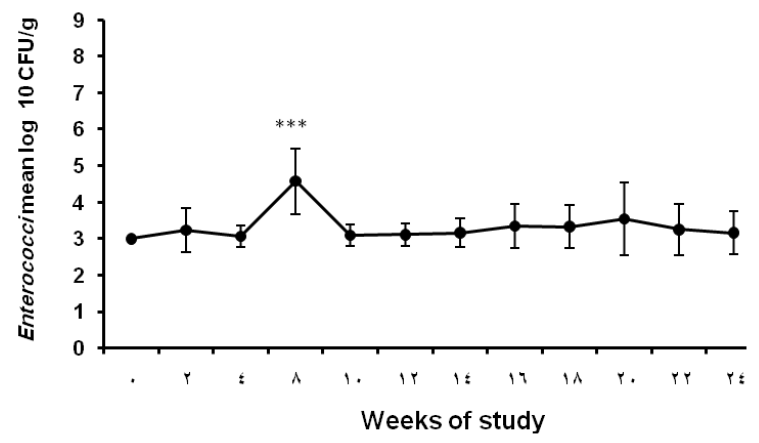

Figure 3: Enterococci in feces of cows supplemented with $400 \mathrm{~g}$ (week 0-4) or $200 \mathrm{~g}$ (week 5-10) of charcoal/d, $200 \mathrm{~g}$ charcoal plus $500 \mathrm{~mL}$ sauerkraut juice $/ \mathrm{d}$ (week 11-14), 120g humic acid/d (week 15-18), 200g charcoal plus $100 \mathrm{ml}$ Aqua humin (week 19-20), 100g charcoal plus $50 \mathrm{~mL}$ Aqua humin (week 21 22) and without supplementation (week 23-26). ${ }^{* * *} \mathrm{P}<0.001$, ${ }^{* *} \mathrm{P}<0.01(\mathrm{~N}=$ 40). and reproduction, protein turnover, memory, inflammation, tumor growth, cancer and metastasis, blood pressure and hypertension all involve one or more critical amino peptidases. A feature common to all metallo-aminopeptidase active sites is that the metal ion (in most cases zinc) is surrounded by a shell of hydrophilic groups that is embedded within a larger environment of hydrophobic groups [12].

After consideration of the immunological results (antibodies), it is not surprising that the immune system of the animals was able to process and present $C$. botulinum antigens to the immune system to express high $\mathrm{CD}$ and middle $\mathrm{ABE}$ antibody levels. The necessary $\mathrm{Zn}^{++}$ions were present above the reference level in the blood of the investigated animals throughout the time of this study. The other trace elements measured were either within the physiological range $(\mathrm{Cu})$, above this range (Se), or very well below the reference ranges (Co and $\mathrm{Mn}$ ). The estimated oversupply of $\mathrm{Zn}^{++}$(Figure $4 \mathrm{D}$ ) seemed to especially influence the outcome of the immunological reaction.

Although Se levels on week $0,14,22$ and 26 were above the reference level, the average GLDH levels were below the reference level of $30 \mathrm{U} / \mathrm{L}$ from week 0 to week 22. The average GLDH level reached 63.2 U/L only at week 26 and this was influenced by a very high maximum value of $1756 \mathrm{U} / \mathrm{L}$ (Table 3). CK was reduced at all sampling times compared to week 0 , but the differences were not significant and the relatively high mean was caused by only one very high value of one cow $(2750 \mathrm{U} / \mathrm{L})$. The average CK values of cows in this study were lower than the CK levels reported for Danish cows [1]. The increased CK, but low blood creatinine levels, low $\mathrm{CK}$ and the low blood creatinine levels indicate muscle cell damage is occurring although there were low, but no significant differences between the blood creatinine levels at any of the sampling times. Urine creatinine levels were different at some sampling times. Plasma creatinine originates from the degradation of creatine and creatine phosphate, which are present mainly in muscle. Table 3 shows significant differences between week 0 and weeks 10, 14, 18, 22 and 26. Urine creatinine levels decreased from the beginning to the end of this investigation even though blood creatinine levels remained unchanged. The reason for the reduced creatinine excretion in urine could be because of reduced muscle degradation by neutralization of glyphosate. Decreased CK (Table 3) after certain supplementations is an indication of this. Another reason could be from increased water intake and dilution of the urine ingredients. Unfortunately, the farmer didn 't measure the water intake of the herd. Blood vitamin B12 levels were within the reference range at weeks 0,4 and 10; however, it was not possible to determine vitamin B12 at the other sampling times.

Fecal bacteriological parameters were influenced by the different supplements. Aerobe total counts were significantly increased on weeks $8,16,20$, and 22; but decreased on weeks 18 and 26; however, these cell counts were not influenced by Gram-negative bacteria at the same sampling times (Figure 2). The causes of these changes in aerobe bacterial counts are not known, but it could be from contamination of the charcoal and humic acids with spore forming aerobic bacteria. Gram negative and Enterococcus bacterial counts (Figures 2 and 3) were significantly higher at 8 and 20 weeks, but the population of Enterococci appears to be too low for an effective antagonism to $C$. botulinum over the full time period. In relation to the constant feeding of the cows with the glyphosate contaminated feed and the changing of different supplements, these results were surprising since Krüger et al. [10] reported antagonistic activity of Enterococcus at populations higher than $10^{3} \mathrm{cfu} / \mathrm{g}$ and the populations in this study appear relatively low. Under in vitro conditions more than $10^{5} \mathrm{cfu} / \mathrm{g}$ Enterococcus cells are necessary to antagonize C. botulinum, but under in vivo conditions 
Citation: Gerlach H, Gerlach A, Schrödl W, Haufe S, Schottdorf B, (2014) Oral Application of Charcoal and Humic Acids Influence Selected Gastrointestinal Microbiota, Enzymes, Electrolytes, and Substrates in the Blood of Dairy Cows Challenged with Glyphosate in GMO Feeds. J Environ Anal Toxicol 4: 256. doi: 10.4172/2161-0525.1000256
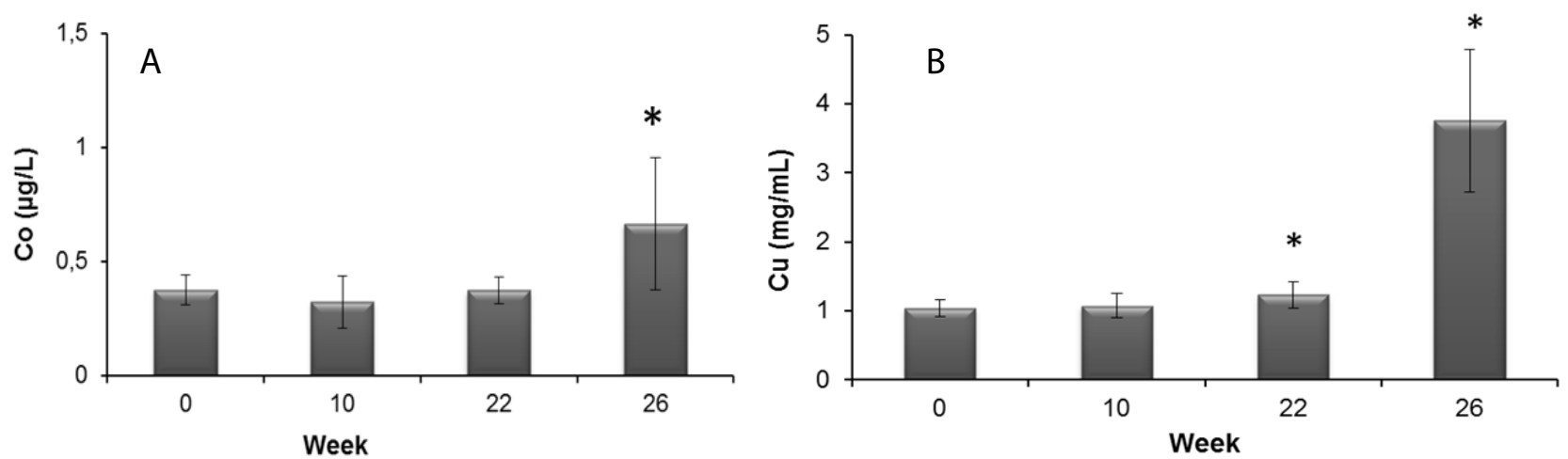

C
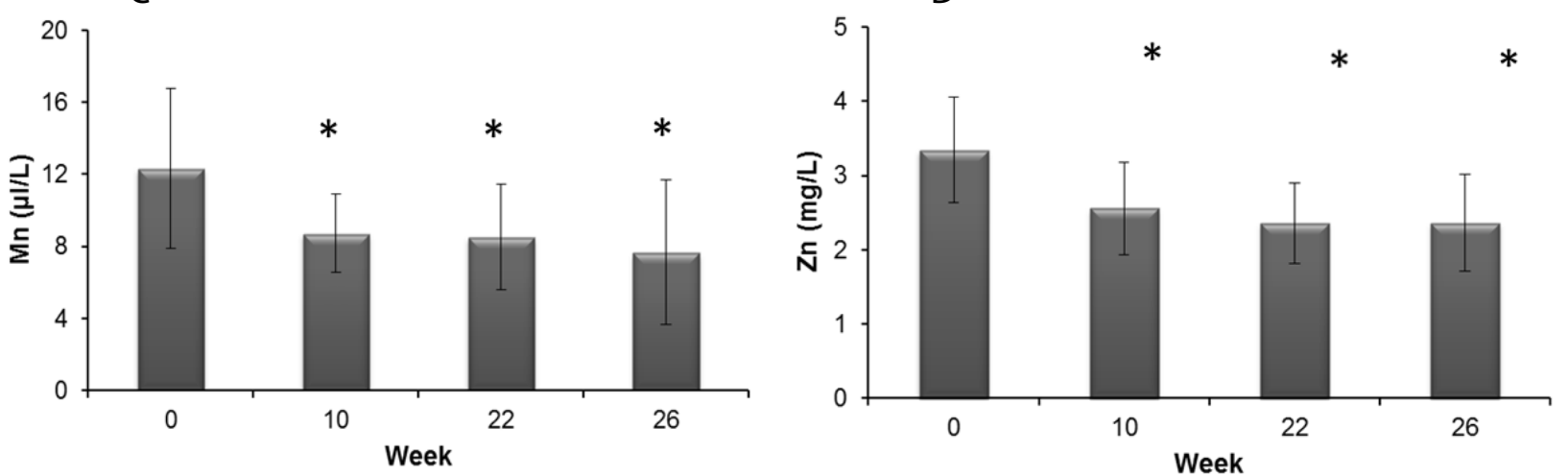

Figure 4: Trace element concentration (A. Co; B: Cu; C: Mn; D: Zn) in whole blood specimens of dairy cows suupplementation with 400 or $200 \mathrm{~g} / \mathrm{d}$ charcoa and $200 \mathrm{~g}$ charcoal plus $500 \mathrm{~mL}$ sauerkraut juice (week 1-14), 120g/d humic acids and $100 \mathrm{or} 50 \mathrm{~mL} / \mathrm{d}$ Aquahumin plus 200 and 100g charcoal (week $15-22$ ) and without substitution (week 23-26). A significant increase in Co occurred between 26 weeks and all the other sampling times ( $<<0.05)$, Cu significantly increased at 22 and 26 weeks in relation to the starting point $(P<0.05)$, and $\mathrm{Zn}$ and $\mathrm{Mn}$ were significantly reduced from point 0 in relation to the other sampling periods $(\mathrm{P}<0.05),(\mathrm{N}=40)$.

more antagonists than Enterococci are present since some strains of C. perfringens, C. sporogenes and Bacillus cereus also antagonize $C$. botulinum types A,B, F and E [12-14].

\section{Conclusions}

These results show that the application of charcoal, sauerkraut juice and humic acids in feed of cows can decrease the excretion of glyphosate by urine and influence enzymes and substrates of treated animals. This improved the animal's health and induced an appropriate immunological reaction to C. botulinum [9]. It must be noted that these animals were also deficient in manganese and cobalt so that additional mineral supplementation with these essential minerals should be evaluated.

\section{References}

1. Krüger M, Schrödl W, Neuhaus J, Shehata AA (2013) Field investigations of glyphosate in urine of Danish dairy cows.

2. Barry G, Padgette SR (1992) Glyphosate tolerant 5-enolpyruvylshikimate-3phosphate synthases. World Patent WO 92/04449.

3. Cerdeira AL, Duke SO (2006) The current status and environmental impacts of glyphosate-resistant crops: a review. J Environ Qual 35: 1633-1658.

4. Lorenzatti E, Maitre MI, Argelia L, Lajmanovich R, et al. (2004) Pesticide residues in immature soybeans of Argentina croplands. Fresenius Environ Bull 13: $675-678$
5. Duke SO, Baerson SR, Rimando AM (2003) Herbicides: Glyphosate. In J R Plimmer, DW Gammon, and NN Ragsdale (eds.) Encyclopedia of Agrochemicals.

6. Sanchís J, Kantiani L, Llorca M, Rubio F, Ginebreda A, et al. (2012) Determination of glyphosate in groundwater samples using an ultrasensitive immunoassay and confirmation by on-line solid-phase extraction followed by liquid chromatography coupled to tandem mass spectrometry. Anal Bioanal Chem 402: 2335-2345.

7. Mazzei P, Piccolo A (2012) Quantitative evaluation of non-covalent interactions between glyphosate and dissolved humic substances by NMR spectroscopy. Environ Sci Technol 46: 5939-5946

8. Shehata AA, Kühnert M, Haufe S, Krüger M (2013) Neutralization of the antimicrobial effect of glyphosate by humic acid in vitro. $\mathrm{J}$ chemosphere 10 258-261.

9. Gerlach H, Gerlach A, Schrödl W, Schottdorf B, Haufe S,et al. (2014) Ora application of charcoal and humic acids to dairy cows influences Clostridium botulinum blood serum antibody level and glyphosate excretion in urine. J Clinical Toxicol 186: 2161-0495.

10. Krüger M. Shehata AA, Schrödl W. Rodloff A (2013) Glyphosate suppresses the antagonistic effect of Enterococcus spp. on Clostridium botulinum. Anaerobe 20: 74-78.

11. Mucha A, Drag M, Dalton JP, Kafarski P (2010) Metallo-aminopeptidase inhibitors. Biochimie 92: 1509-529.

12. Okereke JD, Montville PR (1991) Bacteriocin-mediated inhibition of Clostridium botulinum spores by lactic acid bacteria at refrigeration and abuse temperatures. Appl Environment Microbiol 57: 3423-3428. 
Citation: Gerlach H, Gerlach A, Schrödl W, Haufe S, Schottdorf B, (2014) Oral Application of Charcoal and Humic Acids Influence Selected Gastrointestinal Microbiota, Enzymes, Electrolytes, and Substrates in the Blood of Dairy Cows Challenged with Glyphosate in GMO Feeds. J Environ Anal Toxicol 4: 256. doi: 10.4172/2161-0525.1000256

Page 6 of 6

13. Allison MJ, Stephen EM, Matson HR (1976) Inactivation of Clostridium botulinum toxin by ruminal microbes from cattle and sheep. Approbiol 36: 685688
14. Anastasio KL, Soucheck JA, Sugiyama $H$ (1971) Boticinogeny and action of the bacteriocin. J Bacteriol 107: 143-149. 